\title{
Research on Enterprise Intellectual Property Management Based on
}

\author{
Industrial Engineering \\ Qiannan Wang $^{a, b}$ Lin $^{\mathrm{Ni}^{a, b}}{ }^{\text {, Hongyuan Chang }}{ }^{a, b, c}$, Yingbo $\mathrm{Wu}^{d}, \mathrm{Xu}$ Wang $^{a, b}$ \\ ${ }^{a}$ Chongqing Key Laboratory of Logistics, Chongqing University, Chongqing; \\ ${ }^{\mathrm{b}}$ State Key Laboratory of Mechanical Transmission, Chongqing University, Chongqing; \\ ${ }^{\mathrm{c} C e n t e r ~ f o r ~ m a r i t i m e ~ a n d ~ a i r ~ t r a n s p o r t ~ m a n a g e m e n t ~(C-M A T), ~ F a c u l t y ~ o f ~ A p p l i e d ~ E c o n o m i c s, ~}$ \\ University of Antwerp, Belgium; \\ ${ }^{\mathrm{d}}$ School of software, Chongqing University, Chongqing; \\ *Corresponding author: Lin Ni, associate professor, nilin71@163.com
}

\begin{abstract}
With the development of technology and economy, the competition between enterprises has increasingly depended on intellectual property (IP). To solve many problems of intellectual property management (IPM) in Chinese enterprises, the methods of industrial engineering (procedure analysis, operational analysis, causal analysis and interpretation structure model of technology, ECRS operation process improvement) are applied to improve the enterprises IPM system, IPM process and the specific operation based on domestic IPM work analysis. By effectively addressing the problems of the limitation of IPM system, long period of IPM process, invalid actions, and communication and coordination difficulties between departments, the waiting rate of IPM process can be decreased by about $45 \%$, the IPM personnel flow rate can be decreased by about $20 \%$, and the implementation rate of IP can be improved by about 35\%.
\end{abstract}

Key words: intellectual property management; industrial engineering; procedure analysis; operational analysis; demand analysis

\section{Introduction}

As the development of economic globalization and knowledge economy, the global economic growth mode, the production mode and the industrial structure have been greatly changed. The essence of the ever-changing international market competition is the competition of high-tech science and technology, the competition of knowledge and intelligence, the efficiency and the level of technological innovation competition, which directly evolves into the competition of $\mathrm{IP}^{1}$. The emergence of new technology such as internet plus, big data, information technology, new material technology, artificial intelligence technology stimulates the enterprises to pay more attention to the intangible assets investment. The IP has the characteristics of exclusive, regional, transfer, time, input-output ratio higher ${ }^{2}$, and directly related to enterprise profit, so enterprises become more and more concerned about IPM. In the government work report of 2015, 'innovation' is mentioned about 40 times. President 
$\mathrm{Xi}$ Jinping emphasizes that innovation is the first power to lead the development, and the conversion of scientific and technological innovation is key to lead and adapt the 'new normal' of China's economy ${ }^{3}$. At present, China's innovation system includes the government, research institutions and universities, enterprises, technology innovation supporting service system. However, the enterprise plays an important role in strengthening scientific and technological innovation and promoting conversion and industrialization of scientific and technological achievements. The level of IPM directly affects the national IP strategy formulation and the value of knowledge capital market operation. Because high level of IPM system is a competitive advantage for enterprises in the international market, most of well-known global enterprises tend to strengthen their IPM with the complete IP law, powerful IP database and so on. America is a powerful IP country. Since the 70s of the last century, the United States has already begun to implement globalization offensive IP strategy and obtained obvious competitive edge in the international market ${ }^{4}$.

With the economic globalization and the arrival of the era of knowledge economy, the IP competition of enterprises in the world will become more and more intense. However, Chinese enterprises still lack experience in IPM. So it is very urgent to strengthen IPM, establish the IPM system accordance with the domestic enterprises' actual situation, improve the IPM efficiency, promote the implementation of IP, and prepare to cope with fierce competition in the IP.

\section{Domestic IPM current situation Analysis}

According to the literature review, and through the investigation on the enterprises IPM, IPM process is divided into three stages: proposal approval, intellectual property application, intellectual property implementation.

\section{Proposal approval}

The proposal approval is that enterprise's R\&D department forms a new IP by combining with the means of R\&D and the market prospect analysis. Then IP writers write IP application, and submit to the department supervisor for approval. In this phase it is required to analyze the IP current market distribution, the enterprises existing IP, and make preparation for the IP development and application.

2. Intellectual property application

In the intellectual property application, the company submits the IP applications to the national patent office. At this stage company should be familiar with IP application process, so that it can analyze the situation and the results of IP application, and form the intangible wealth of enterprises, prepare for the next IP application.

\section{Intellectual property implementation}

Intellectual property implementation contains strategic research and implementation, IP protection, IP licensing and transfer, IP intellectual property disputes and treatment. As an important part of the whole IPM, this stage can directly bring huge economic benefits for 
company.

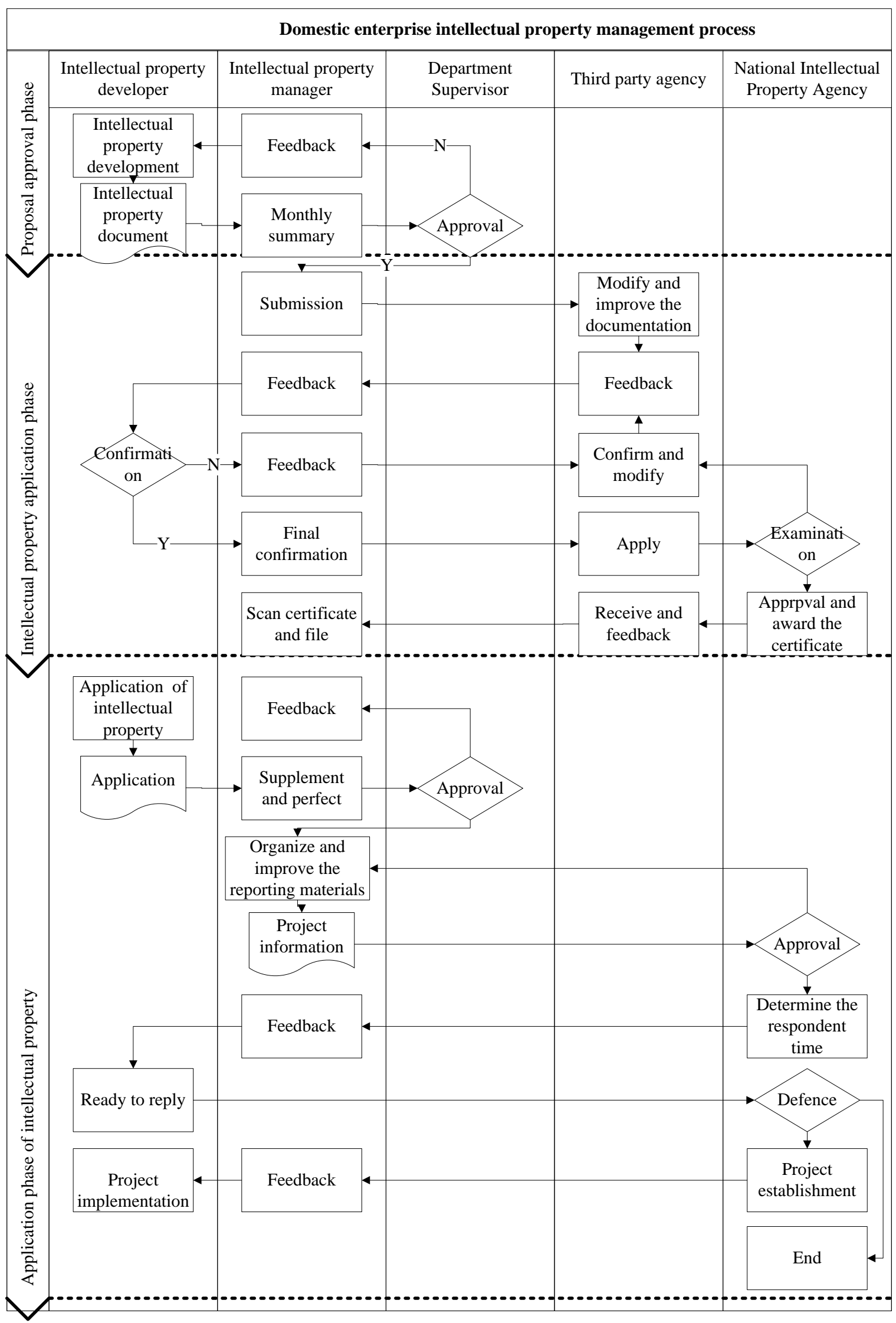

Fig. 1 - Domestic enterprise intellectual property management process 
The above Fig. 1 makes a conclusion for the IPM processes of Chinese companies. (figure 1) shows that the IPM process is too tedious and low efficiency. In order to clearly understand all this, an industrial engineering method called causal analysis is used. The following (figure 2) shows the details of causal analysis, including four aspects - man, machine, method and environment. The main problems existing in the domestic enterprise IPM are: 1 . incomplete contents; 2. Lack of an effective IPM tools or IPM tools are outdated; 3. many invalid operation and cumbersome IPM process; 4. Lack of coordination among the various departments.

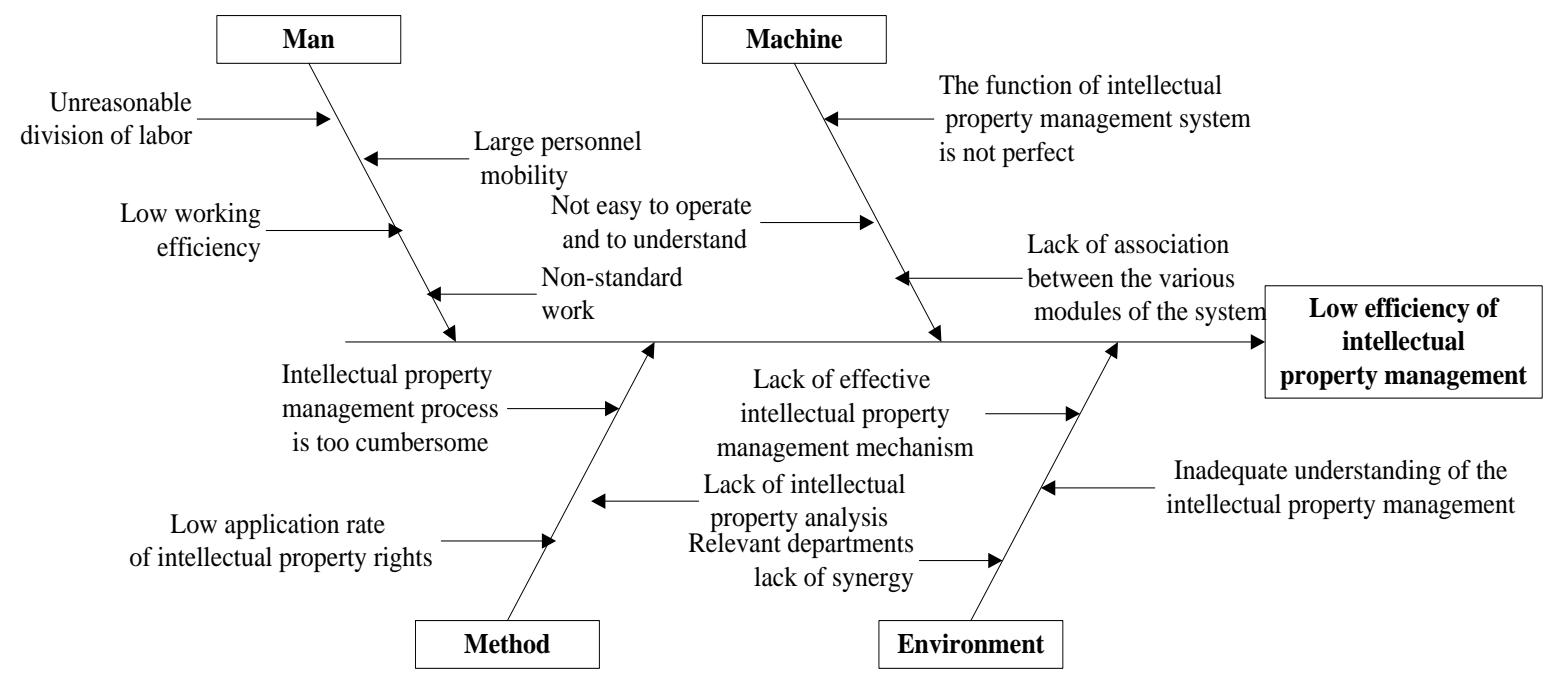

Fig. 2 - Domestic enterprise intellectual property management inefficient causal analysis chart

\section{Intellectual property management process improvement}

\subsection{Program analysis}

(figure 2) shows that the current domestic enterprise IPM is not comprehensive, many only focus on the number of IP, lack of a sound IPM system. To know the practice in detail, interviews are made in this paper. Through interviewing IPM person with business-related, existed IPM problems, and recommendations and summary the IPM needs are collected to make the following interview summary table which summarizes the various stages of the IPM. As shown in (table 1 3).

\subsection{Program improvement}

By program analysis, current IPM function is not perfect, which has become the bottleneck of enterprise IP management, so it is necessary to improve the enterprise IPM starting from the IPM function demand.

First, summarize the demand of IPM processes at various stages according to the program analysis, as shown in (table 4). 
Table 1 - Interview summary table of the proposal approval stage

\begin{tabular}{|c|c|c|c|}
\hline $\begin{array}{l}\text { Personnel } \\
\text { Category }\end{array}$ & Problems & Suggestion & $\begin{array}{l}\text { Functional } \\
\text { Requirements }\end{array}$ \\
\hline $\begin{array}{l}\text { Intellectual } \\
\text { property } \\
\text { developer } \\
\text { and writer }\end{array}$ & $\begin{array}{l}1 \text { In the preparation of the } \\
\text { application, the developer doesn't } \\
\text { have a good use of the company's } \\
\text { existing IP resources and the existing } \\
\text { resources at home and abroad; } 2 \text { In } \\
\text { the preparation of the application, the } \\
\text { writer cannot combine the IP with the } \\
\text { actual production, resulting in the } \\
\text { majority of IP don't have practical } \\
\text { value; } 3 \text { New R \& D project almost } \\
\text { doesn't do any IP strategy analysis, } \\
\text { easily lead to duplication research } \\
\text { and development, waste of resources } \\
\text { and other issues; } 4 \text { Submit approval } \\
\text { cycle is too long. }\end{array}$ & $\begin{array}{l}1 \text { Proposed the } \\
\text { establishment of IP } \\
\text { database and other } \\
\text { infrastructure facilities; } 2 . \\
\text { Before the IP development, } \\
\text { careful select the object, } \\
\text { through retrieve the } \\
\text { appropriate analysis to } \\
\text { help determine; } 3 . \\
\text { Establish approval system, } \\
\text { instant approval, do not } \\
\text { have to collect a month for } \\
\text { approval. }\end{array}$ & $\begin{array}{lr}1 & \text { Intellectual } \\
\text { property } & \text { literature } \\
\text { search database } \\
2 & \text { Proposal } \\
\text { approval system }\end{array}$ \\
\hline $\begin{array}{l}\text { Intellectual } \\
\text { property } \\
\text { manager }\end{array}$ & $\begin{array}{l}1 \text { The department supervisor is too } \\
\text { busy, often leading to a longer } \\
\text { approval time; } 2 \text { The reply is only a } \\
\text { verbal reply, no formal draft notice; } 3 \\
\text { Feedback the approval results to the } \\
\text { corresponding patent writers, the } \\
\text { workload is large and the efficiency } \\
\text { is not high. }\end{array}$ & $\begin{array}{l}\text { 1. Increase IPM staff } \\
\text { privileges of the } \\
\text { application approval, } \\
\text { submit the marked } \\
\text { application to department } \\
\text { supervisor, and reduce } \\
\text { processing time; } 2 . \\
\text { Establish approval system, } \\
\text { IP writers can log in to } \\
\text { view the approval results. }\end{array}$ & $\begin{array}{l}\text { 1.Increase the IPM } \\
\text { staff privileges; } \\
2 . \quad \text { Establish } \\
\text { approval system. }\end{array}$ \\
\hline $\begin{array}{l}\text { Department } \\
\text { supervisor }\end{array}$ & $\begin{array}{l}\text { 1. Only one person in charge of IP } \\
\text { application review, workload larger } \\
\text { and time constraints, which is likely } \\
\text { to cause the results bias; } 2 \text {. When } \\
\text { review the application, it cannot } \\
\text { quickly see enterprises existing IP, } \\
\text { leading to a longer review time. }\end{array}$ & $\begin{array}{l}1 \text { Carry out the training of } \\
\text { IPM personnel and make } \\
\text { them assist in the } \\
\text { application review; } 2 \\
\text { Establish internal and } \\
\text { external IP literature } \\
\text { search database. }\end{array}$ & $\begin{array}{l}\text { 1. Establish of IP } \\
\text { template index; } 2 \\
\text { Increase system } \\
\text { security design. }\end{array}$ \\
\hline
\end{tabular}


Table 2 - Interview summary table of the intellectual property application stage

\begin{tabular}{|c|c|c|c|}
\hline $\begin{array}{l}\text { Personnel } \\
\text { Category }\end{array}$ & Problems & Suggestion & $\begin{array}{l}\text { Functional } \\
\text { Requirements }\end{array}$ \\
\hline $\begin{array}{l}\text { Intellectual } \\
\text { property } \\
\text { developer } \\
\text { and writer }\end{array}$ & $\begin{array}{l}\text { With the development and growth } \\
\text { of enterprises, IP application by the } \\
\text { third party agency is not conducive } \\
\text { to the long-term development of the } \\
\text { enterprise. }\end{array}$ & $\begin{array}{l}\text { Build enterprise } \\
\text { applications module of } \\
\text { their IPM system and train } \\
\text { internal IP applicants }\end{array}$ & $\begin{array}{l}\text { Increase the IP } \\
\text { application function. }\end{array}$ \\
\hline $\begin{array}{l}\text { Intellectual } \\
\text { property } \\
\text { manager }\end{array}$ & $\begin{array}{l}1 \text { There are some technical secrets } \\
\text { in the application, so there is a } \\
\text { certain security risk give the apply } \\
\text { to the third party agencies; } \\
2 \text { Not participate in the application } \\
\text { process, which will cause the staffs } \\
\text { are not enough familiar with } \\
\text { application process, lack of insight } \\
\text { into the dynamic of technology }\end{array}$ & $\begin{array}{l}\text { 1. Increase the technology } \\
\text { security management in } \\
\text { application; } 2 \text { Participate } \\
\text { in the work of the IP } \\
\text { application stage, finishing } \\
\text { the filing of each } \\
\text { application and make a } \\
\text { summary, prepare for the } \\
\text { subsequent application. }\end{array}$ & $\begin{array}{l}\text { 1. Increase the } \\
\text { technological security } \\
\text { means; } \\
\text { 2. Increase knowledge } \\
\text { acquisition and } \\
\text { storage; } \\
\text { 3. Increase knowledge } \\
\text { classification }\end{array}$ \\
\hline
\end{tabular}

Table 3 - Interview summary table of the intellectual property implementation stage

\begin{tabular}{|c|c|c|c|}
\hline $\begin{array}{l}\text { Personnel } \\
\text { Category }\end{array}$ & Problems & Suggestion & $\begin{array}{l}\text { Functional } \\
\text { Requirements }\end{array}$ \\
\hline $\begin{array}{l}\text { Intellectual } \\
\text { property } \\
\text { developer } \\
\text { and writer }\end{array}$ & $\begin{array}{l}\text { 1. Many IP applications do not } \\
\text { follow in use, resulting in a waste } \\
\text { of resources; } \\
2 \text { Project implementation personnel } \\
\text { not involved in the project } \\
\text { application, which cause } \\
\text { difficulties for project } \\
\text { implementation. }\end{array}$ & $\begin{array}{l}\text { 1. Enterprise through } \\
\text { licensing, shares and } \\
\text { transfer mode, realize the } \\
\text { income of IP; } \\
2 \text { Establish project } \\
\text { reporting module, } \\
\text { authoring process in } \\
\text { accordance with the } \\
\text { declaration, certain } \\
\text { privileges should be given } \\
\text { to project implementation, } \\
\text { allowed them to } \\
\text { participate. }\end{array}$ & $\begin{array}{l}\text { 1. Increase the IP } \\
\text { transfer, IP licensing, } \\
\text { IP shares modules; } \\
\text { 2. Increased project } \\
\text { implementation } \\
\text { process management; }\end{array}$ \\
\hline $\begin{array}{l}\text { Intellectual } \\
\text { property } \\
\text { manager }\end{array}$ & $\begin{array}{l}\text { 1. Personnel liquidity and ignoring } \\
\text { intangible asset in valuation } \\
\text { assessment result in the loss of IP; } \\
\text { 2. Insufficient IP protection } \\
\text { awareness, which often arise IP } \\
\text { disputes; } \\
\text { 3. Lack of effective cost } \\
\text { management }\end{array}$ & $\begin{array}{l}\text { 1. Establish a personnel } \\
\text { management system; } 2 . \\
\text { Strengthen the evaluation } \\
\text { of intangible assets in the } \\
\text { enterprise evaluation, take } \\
\text { serious of IP protection; } \\
\text { 3. Sort out the IP cost, } \\
\text { achieve effective costs } \\
\text { management. }\end{array}$ & $\begin{array}{l}\text { 1. Increase the } \\
\text { personnel } \\
\text { management; } \\
2 \text {. Increase IP and } \\
\text { other intangible assets } \\
\text { assessment } \\
\text { management. } \\
\text { 3.Increase the cost } \\
\text { management }\end{array}$ \\
\hline
\end{tabular}


Table 4 - Summary of program analysis function needs of various stages

\begin{tabular}{|l|l|}
\hline Phase & Demand Function Summary \\
\hline proposal approval phase & $\begin{array}{l}\text { IP literature search database, proposal and approval application } \\
\text { template index, IPM. }\end{array}$ \\
\hline $\begin{array}{l}\text { intellectual property application } \\
\text { phase }\end{array}$ & $\begin{array}{l}\text { technical secrets management, IP applications, open technologies } \\
\text { management, knowledge acquisition and storage category }\end{array}$ \\
\hline $\begin{array}{l}\text { intellectual property implementation } \\
\text { phase }\end{array}$ & $\begin{array}{l}\text { IP implementation, IP transfer, IP licensing, IP investment, IP } \\
\text { sharing, IP staff management, knowledge base management, } \\
\text { project implementation cost management, IP awards, other costs } \\
\text { management, security management, IP protection, IP infringement }\end{array}$ \\
\hline
\end{tabular}

Interpretative structural modeling technique is used to stratify and classify system functions obtained from demand analysis, and then the IPM system function structure is built, shown in (figure 3). It includes four modules: knowledge base management, intellectual property management, cost management, system management.

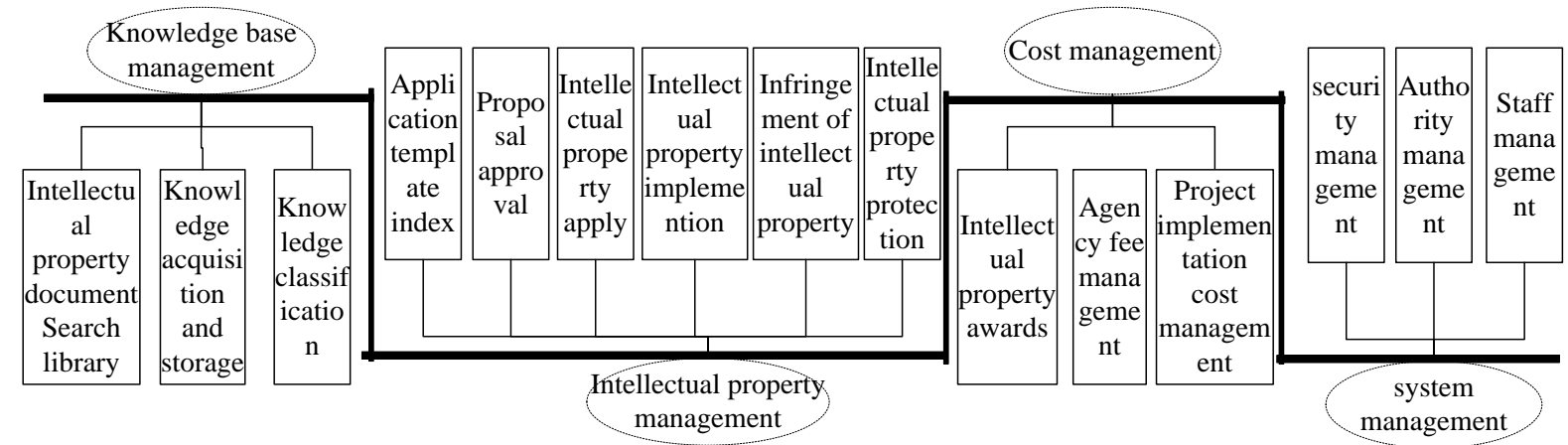

Fig. 3 - Intellectual property management system function structure

According to the functional structure to build or improve the enterprises' IPM system, and according to the principles of ECRS to improve IPM processes, here author will not go into the specific process, the enterprise IPM processes after improvement at all stages are shown in (Fig. 4 6):

In improved proposal approval stage, IP developers can retrieve relevant IP at home and abroad about the situation of IP development, determine the direction of IP development through IP library literature database. Application writers through the application template index quickly write application, developers write the part of technologies related, which can reduce the time of communication and coordination; The application is directly submitted in the system after completing, it doesn't need to be aggregated to the IP manager and wait a month. In the system it should obtain the initial approval from IP manager, then the second approval from the department supervisor, by which can reduce the workload of the department supervisor, and shorten the approval cycle.

In improved intellectual property application process, cost management function is increased, which can effective manage the reward cost and application cost and other costs, and make cost management easier and efficient; Knowledge acquisition and storage function is 
increased, it can help enterprise to accumulate experience of intellectual property application, and provide assistance for further intellectual property development and application.

In improved IP implementation process, IP implementation module is established, The IP of have not transformation and implementation is labeled and set reminders, which can effectively improve the rate of IP implementation; Connect developer, managers and department supervisor through IP implementation, eliminating the tedious submission steps and reducing communication time.

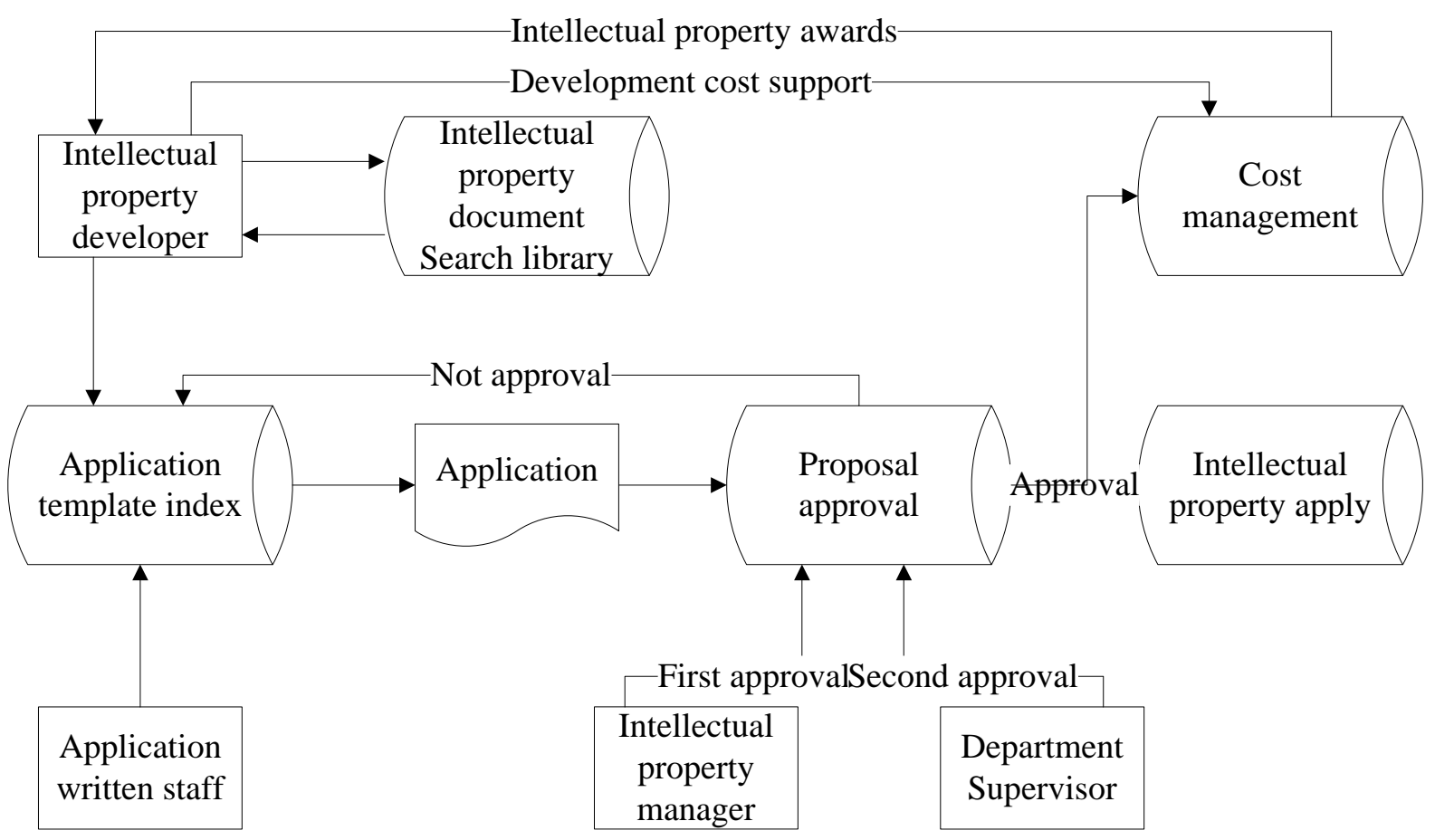

Fig. 4 - Flow chart of proposal approval stage after improvement 


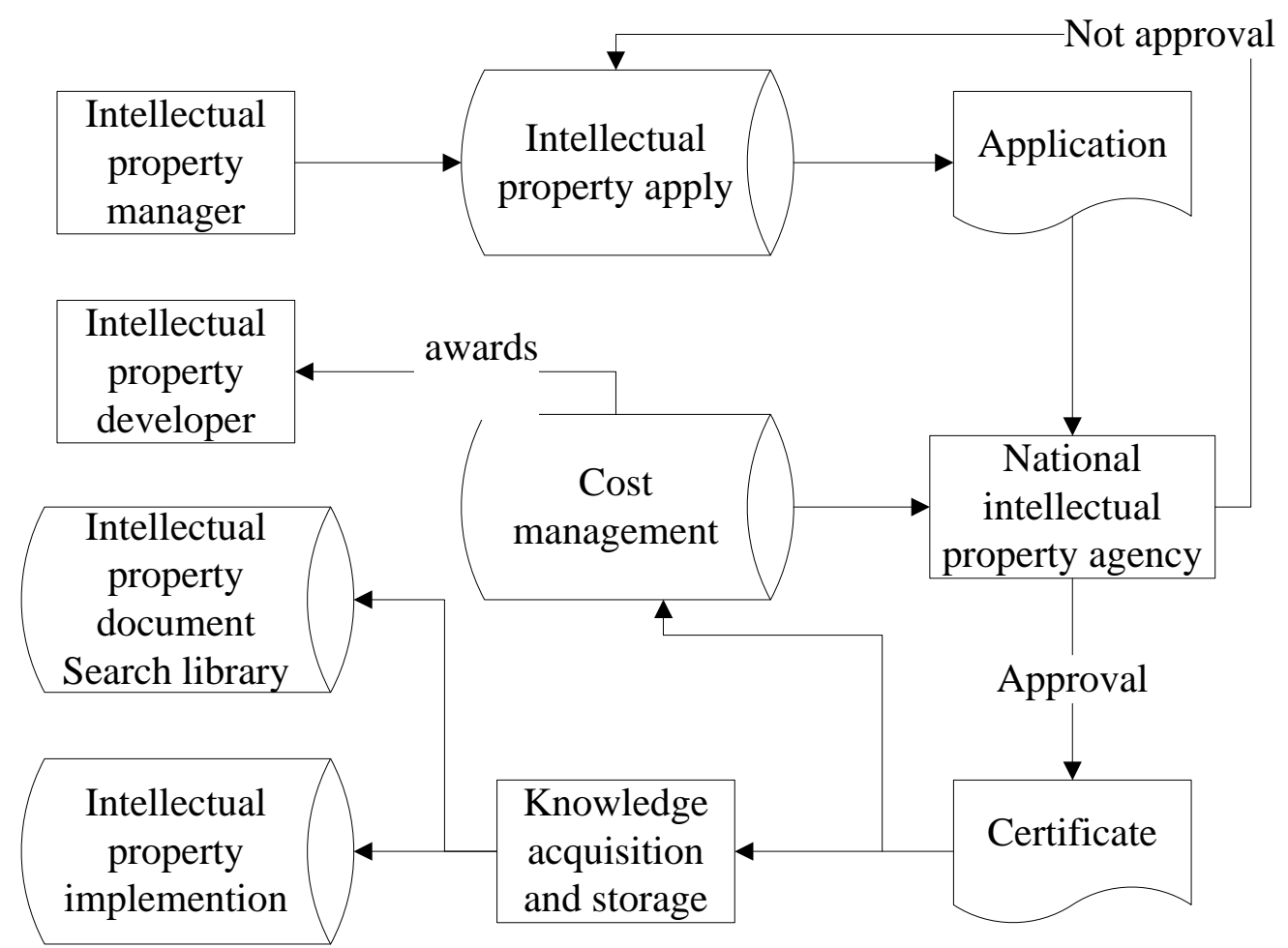

Fig. 5 - Flow chart of intellectual property application stage after improvement

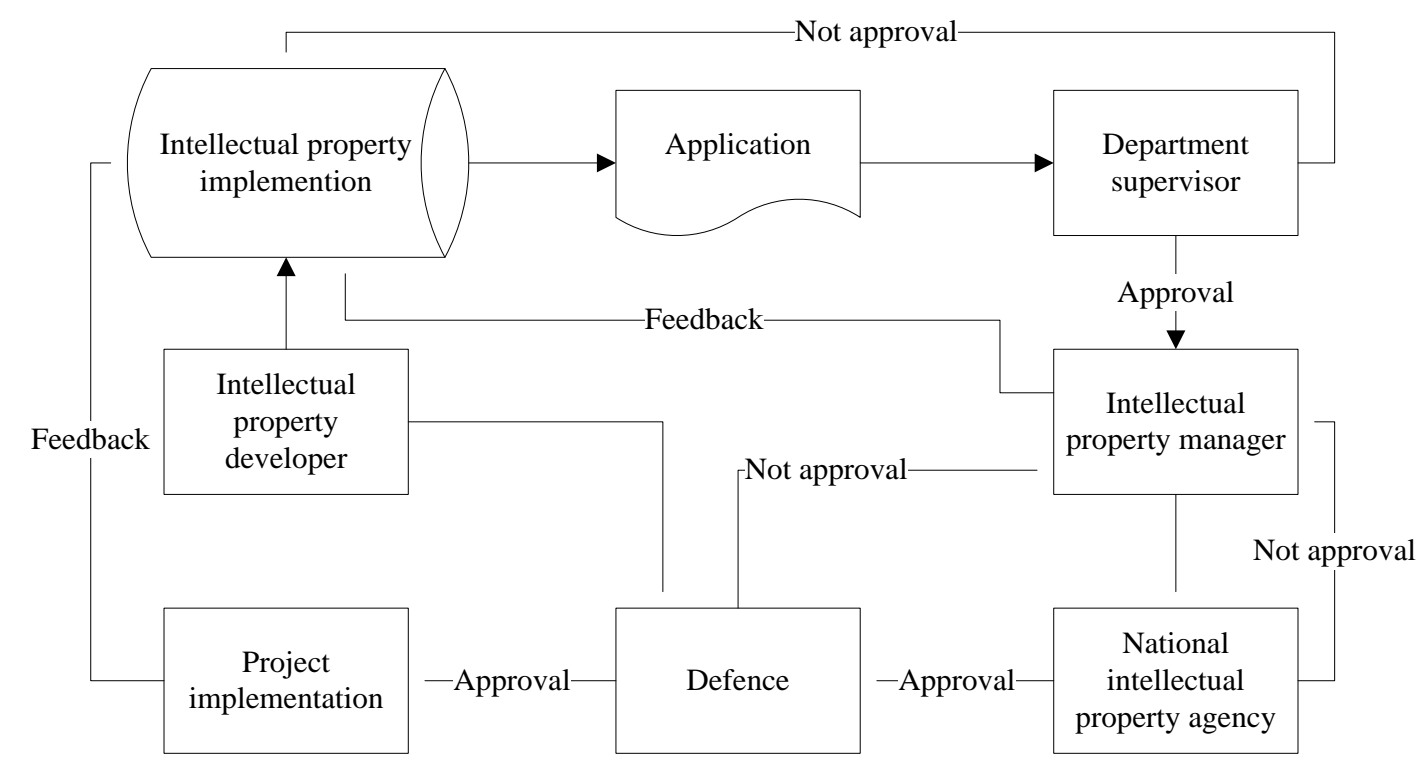

Fig. 6 - Flow chart of intellectual property implementation stage after improvement

\section{Results and Discussion}

With IPM tools becomes more systematic, IPM work process more standardization, IPM staffs are also increasingly standardized, and tend to be more specialized.

Through research on an enterprise of IPM personnel flow rate, and IP implementation rate, and the waiting rate of IPM process of near 5 years, As shown in (figure 7), which 2011 and 2012 has not improved, from 2013 began used the IPM system and the IPM process of this 
paper building, from (figure 7) can see.

4. The IPM personnel flow rate after improved gradually declined, to 2015 maintained in $15 \%$ around, personnel tend to be stable;

5. IP implementation rate increased from $30 \%$ to $70 \%$, connect the IP development with enterprise practice, create a great benefit for enterprise;

6. The waiting rate of IP processes have fallen sharply, dropped from $80 \%$ before to $35 \%$, the efficiency of IPM is greatly improved.

By comparing before and after the improvement on IPM found that the proposed IPM improvement based on industrial engineering can effectively solve the problems mentioned in above: 1. IPM processes is not comprehensive; 2 . Lack of an effective IPM tools or IPM tools out-date; 3 . There are many operation did not have the value; 4 . Lack of coordination among the various departments.

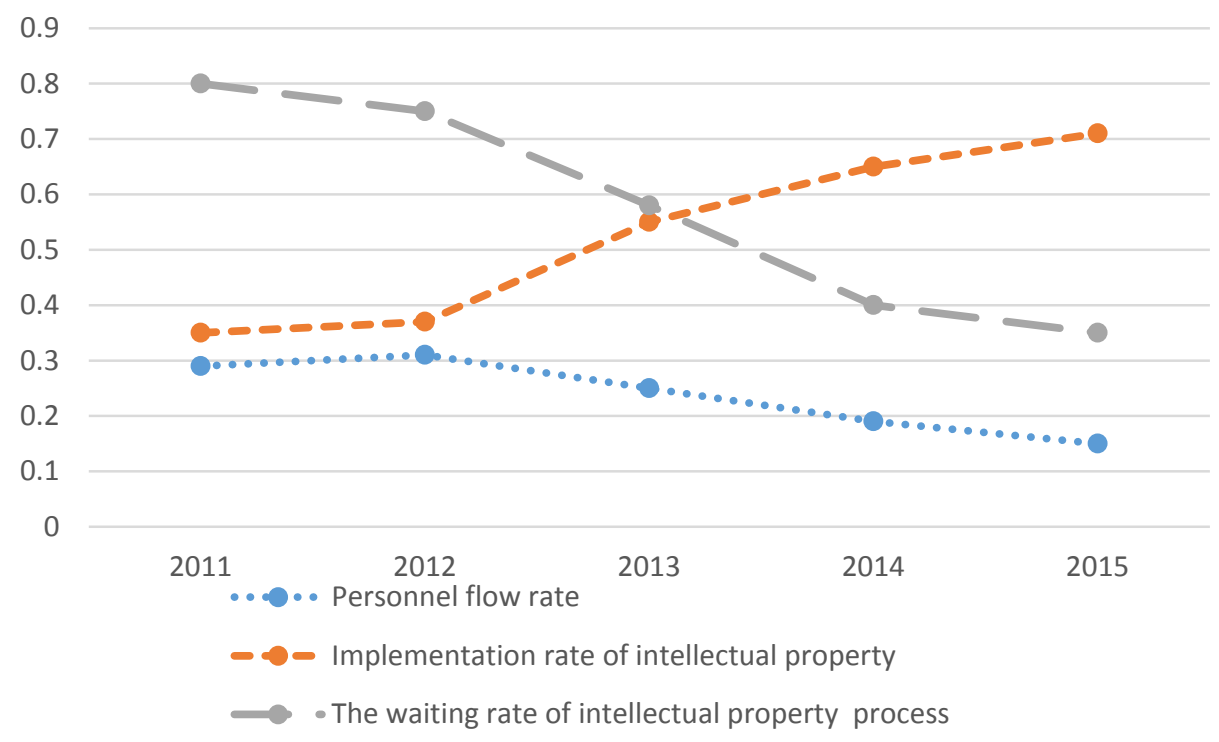

Fig.7 - Before and after improvement intellectual property management comparison chart

\section{Conclusion}

By using the method of industrial engineering (including program analysis, causal analysis, interpretative structural modeling technology and ECRS operation process improvement), and interviews, this paper obtains user demands of IPM system, constructs the IPM system function structure, improves the IPM process, and solves the problems of IPM content limitation, long period of proposal approval, invalid movements, communication difficult between departments and so on. And then through the comparison analysis of enterprise IPM before and after improvement, the IPM personnel flow rate and the waiting rate of IPM processes are greatly reduced, the IP implementation rate has a substantial increase, great progress has been made in the IPM work. However, one important thing needed to be noticed is that this paper is not involved in the specific design of the intellectual property management system, which can be further deepened in the follow-up study. 


\section{Acknowledgements}

At the point of finishing this paper, I'd like to express my sincere thanks to all those having lent me hands in the course of my writing this paper. First of all, my deepest gratitude goes to Professor Ni, my supervisor, for his constant guidance. Secondly, I want to thank my classmates gave me a lot of advice and has helped much on my English translation. Finally, thanks to the corporates give full support for my research, and thanks to the National Natural Science Foundation of China under Grant No.71301177, National Science and Technology Support Program of China under Grant No.2015BAH46F01 and 2015BAF05B03, the Research Fund for the Doctoral Program of Higher Education under Grant No. 20130191110045, the Fundamental Research Funds for the Central Universities Project under Grant No. CDJZR13110048 and No. 0225005202013, CDJZR14110001 and 106112015CDJSK02JD05, and the Chongqing City Key Science Program Project under Grant No. cstc2014yykfA40006 and cstc2015yykfC60002, gave me the direction and provided me a lot of resources.

\section{References}

1. A. R. Miller, Intellectual property: Patents, Trademarks, and Copyright.

Entrepreneur Press, New York, 1997, str.1-4.

2. H. Candelin-Palmqvist, B. Sandberg, U. M. Mylly, Intellectual property rights in innovation management research: a review, J. Technovation, 32(2012)502-512.

3. URL: http://politics.people.com.cn/n/2015/0308/c70731-26656427.html (8.3.2015).

4. S. Giordani, Re-thinking the Role of Intellectual Property in Nano-Strategy, J. Nanotechnology Reviews, 1(2012)97-102. 